\title{
Effect of smoking on blood lead levels in workers and role of reactive oxygen species in lead-induced sperm chromatin DNA damage
}

\author{
Ping-Chi Hsu, Ph.D., ${ }^{\mathrm{a}}$ Ho-Yuan Chang, Sc.D., ${ }^{\mathrm{b}}$ Yueliang Leon Guo, M.D., Ph.D., ${ }^{\mathrm{c}}$ \\ Yen-Chun Liu, Sc.B., ${ }^{\mathrm{a}}$ and Tung-Sheng Shih, Sc.D. ${ }^{\mathrm{d}, \mathrm{e}}$ \\ ${ }^{a}$ Department of Safety, Health and Environmental Engineering, National Kaohsiung First University of Science and \\ Technology, Kaohsiung; ${ }^{\mathrm{b}}$ Graduate Institute of Environmental and Occupational Health, College of Medicine, National \\ Cheng Kung University Medical College, Tainan; ${ }^{c}$ Department of Environmental and Occupational Medicine, National \\ Taiwan University (NTU) and NTU Hospital, Taipei; ${ }^{\mathrm{d}}$ Institute of Occupational Safety and Health, Council of Labor \\ Affairs, Taipei; and ${ }^{\mathrm{e}}$ Graduate Institute of Environmental Health, College of Public Health, China Medical University, \\ Taichung, Taiwan
}

\begin{abstract}
Objective: To investigate whether cigarette smoking affects the blood lead levels (BLL) and whether exposure to lead introduces sperm chromatin DNA damage in factory workers.

Design: Cross-sectional study.

Setting: A battery plant in Taiwan.

Patient(s): Eighty male workers employed within a battery plant.

Intervention(s): Standard semen analysis was performed according to the World Health Organization guidelines. Main Outcome Measure(s): Assessment of BLL, sperm chromatin DNA structure, reactive oxygen species generation and other conventional parameters of semen quality.

Result(s): As compared with nonsmoking workers, the BLL were found to be considerably higher among smokers. Statistically significant differences were found in the sperm DNA denaturation $(\alpha \mathrm{T})$ induction and the percentage of sperm with increased DNA denaturation (COMP $\alpha \mathrm{T})$ in workers with moderate BLL $(\geq 25 \mu \mathrm{g} /$ dL). After adjustment for smoking propensity, a positive correlation was discernible between BLL and $\alpha \mathrm{T}$, COMP $\alpha \mathrm{T}$, and morphologic abnormality. Furthermore, $\alpha \mathrm{T}$ and COMP $\alpha \mathrm{T}$ were also found to have positive correlations with sperm superoxide anion production.

Conclusion(s): Workers with higher BLL were found to be at a higher risk of sperm morphologic abnormality and chromatin DNA integrity. These data are significant because they can facilitate the estimation of lead exposure in reproductive toxicology. (Fertil Steril ${ }^{\circledR} 2009 ; 91: 1096-103$. @2009 by American Society for Reproductive Medicine.)
\end{abstract}

Key Words: Lead exposure, smoking, blood lead levels, sperm chromatin DNA

Lead $(\mathrm{Pb})$ is a ubiquitous environmental and industrial pollutant that has been detected in virtually all phases of environmental and biological systems. The occupational exposure of a father just before conception is thought to increase the risk of cancer in his offspring through toxic inheritance (1). One of the causal mechanisms for such an association is thought to be that occupational exposure may bring about a genetic change in the father's sperm, which may ultimately affect the susceptibility of his children to cancer. Although numerous studies have indicated that lead does generally

Received July 27, 2007; revised and accepted January 2, 2008; published online March 14, 2008.

P.-C.H. has nothing to disclose. H.-Y.C. has nothing to disclose. Y.L.G. has nothing to disclose. Y.-C.L. has nothing to disclose. T.-S.S. has nothing to disclose.

Supported in part by the National Science Council (NSC 94-2314-B-327001) and the Institute of Occupational Safety and Health (IOSH) of Taiwan.

Reprint requests: Tung-Sheng Shih, Sc.D., No. 99, Lane 407, Hengke Road, Sijhih City, Taipei County 22143, Taiwan (FAX: +886-226607731; E-mail: stone@mail.iosh.gov.tw). seem to be genotoxic in mammalian cells $(2,3)$, epidemiologic information on the genotoxic effects in germ cells has been very limited; indeed, it remains a mystery as to whether lead is carcinogenic to humans.

During the later stages of mammalian spermatogenesis, chromatin structure is found to be completely reorganized through a series of sequential steps that result in the removal of nucleosomal histones and their replacement with small, arginine-rich protamines (4). Lead did not appear to have any association with the sperm oxidative DNA damage when the concentration of lead in seminal plasma was below $1.0 \mu \mathrm{g} / \mathrm{dL}$ (5). However, although much work has been undertaken to determine the clastogenicity of lead compounds through the investigation of the chromosomal aberrations in lymphocytes of workers exposed to lead (6-8), there remains a lack of precise data to facilitate the study of the genotoxic effects on sperm chromatin.

The structure of chromatin in the sperm nucleus is a relevant factor for reproductive toxicology essentially because 
there is the potential for chromatin damage anywhere along the male reproductive tract, thereby compromising male fertility and offspring development. Indeed, several studies have reported that alterations in sperm chromatin conformation may diminish human fertility (9-11). Sperm chromatin structure analysis (SCSA) by means of flow cytometry has become a useful tool for the evaluation of sperm quality in reproductive studies. This is a technique that has been widely used in epidemiologic studies for the identification of potential reproductive hazards $(12,13)$.

Excessive reactive oxygen species (ROS) generation may prove to be an important mediator of the damage to cell structures, including lipids and membranes, proteins, and nucleic acids (14); indeed, there is growing evidence to suggest that transition metals, particularly iron and copper, can produce ROS, which result in lipid peroxidation, DNA damage, and depletion of the cell antioxidant defense systems. However, the mechanisms that cause lead to induce oxidative stress on sperm DNA damage are not completely understood.

To learn more about the potential relationship between lead exposure and genetic risk in germ cells, we investigated the alterations in sperm chromatin structure and conventional semen quality observed in workers exposed to lead in a battery plant in Taiwan, with blood lead levels (BLL) as the biomarkers of lead exposure. We began by examining the percentage of sperm associated with the excessive production of superoxide anion $\left(\mathrm{O}_{2}^{-{ }^{-}}\right)$and hydrogen peroxide $\left(\mathrm{H}_{2} \mathrm{O}_{2}\right)$, which was determined as ROS generation. This was then followed by analysis of the correlations among BLL, sperm chromation DNA integrity, conventional semen quality, and sperm ROS generation.

\section{MATERIALS AND METHODS Patients}

Our study sample comprised a population of 167 male workers employed in a battery plant in Taiwan. A total of $80(48 \%)$ men agreed to participate. Our experimental protocol was approved by the institutional review board at the $\mathrm{Na}-$ tional Cheng Kung University Medical Center Human Subjects Committees. All of the participants were fully aware of the entire experimental procedure, and they were also very clear as to their right to withdraw; all participants signed a written consent form and agreed to provide semen samples for this study. All of the men indicated that they were not taking any medications and that they had not been exposed to any substances that were known to influence the study variables.

Background information on all participants was collected by individual questionnaire interviews, with the questions covering occupational, medical, and reproductive history, alcohol and tobacco use, propensity for hot baths, and marital status. Workers who indicated they consumed beer, wine, liquor, or any other alcoholic beverage at least once a week for the past 12 months were defined as "current drinkers." None of the participants reported any urologic or andrologic disorders during the interviews, including history of testicular injury, surgery, or cryptorchidism. Similarly, the reports provided by the annual health examinations on the study participants did not reveal any physician-diagnosed urologic or andrologic disorders.

A Perkin-Elmer model 5100 atomic absorption spectrophotometer (Perkin-Elmer, Norwalk, CT) equipped with an HGA-600 graphite furnace and a deuterium arc background corrector was used to determine blood lead levels, with a 283.3-nm absorption wavelength being adopted. Blood lead standards included bovine whole blood certified materials at concentration between 1 and $100 \mu \mathrm{g} / \mathrm{dL}$. The $r^{2}$ of the calibration curve was at least above 0.995 . An external quality assurance/quality control (QA/QC) program was used to ensure the accuracy and consistency of BLL; the QA/QC program was accepted by the Institute of Occupational Safety and Health of Taiwan $(15,16)$.

\section{Analysis of Semen Quality}

Semen samples were collected by masturbation in the week after the collection of the blood samples. Participants were instructed to abstain from ejaculation for at least 3 days before their appointment to provide semen specimens. A volume of $10 \mu \mathrm{L}$ of semen was held in a Makler chamber (Sefi Medical Instruments, Haifa, Israel) for sperm count and motility measurement.

Sperm morphologic characteristics were subsequently evaluated on air-dried smears stained with trypan blue in a $10 \%(v / v)$ formaldehyde solution and scored at $\times 1000$ magnification under a light microscope. At least 400 sperm per sample were categorized as normal (or abnormal) according to the presence (or absence) of head, neck, and tail as well as any defects in terms of immaturity. Sperm count, morphology, and motility were evaluated in accordance with World Health Organization guidelines (17). All interviews, examinations, and laboratory tests were performed in a blinded fashion.

Within 1 hour of collection, an aliquot of semen was diluted with at least 1:1 human tubule fluid medium to obtain a concentration suitable for computer-assisted semen analysis (CASA), were loaded into the Makler chamber, and were videotaped with the use of negative phase-contrast microscopy. The videotapes were analyzed later for sperm motion with a Hamilton Thorne Research motility analyzer (version HTM-IVOS Specification, Beverly, MA) at a temperature of $37^{\circ} \mathrm{C}$.

The computer-assisted semen analysis was performed for the assessment of sperm motility under the following parameters: [1] the velocity of a cell along the original track (curvilinear velocity, VCL); [2] the velocity along a smoothed path (average path velocity, VAP); [3] the velocity measured along the direct path between two points (straight-line velocity, VSL); [4] the frequency of alternating track direction (beat cross-frequency, $\mathrm{BCF}$ ); and [5] the average amplitude of the lateral head displacement (ALH). 


\section{Sperm Chromatin Structure Assay (SCSA)}

The flow cytometry SCSA described by Evenson et al. (18) detects the susceptibility of sperm to in situ acid denaturation of DNA. Briefly, the samples were treated for 30 seconds with $400 \mu \mathrm{L}$ of a solution of $0.1 \%$ Triton $\mathrm{X}-100,0.15 \mathrm{M} \mathrm{NaCl}$, and $0.08 \mathrm{~N} \mathrm{HCl}, \mathrm{pH} 1.2$. After 30 seconds, $1.2 \mathrm{~mL}$ of staining buffer was added to the test tube and analyzed by flow cytometry. Excitation with a 488-nm wavelength light causes the acridine orange, intercalated into the double-stranded DNA, to emit a green fluorescence $(515-530 \mathrm{~nm})$, whereas singlestranded DNA fluoresces red $(\geq 630 \mathrm{~nm})$.

A minimum of 7000 cells in each sample were analyzed by flow cytometry (Becton Dickinson, San Jose, CA) with a data handler (CellQuest software program, Becton Dickinson). The extent of DNA denaturation per cell was quantified as alpha- $\mathrm{T}(\alpha \mathrm{T})$, expressed as a ratio, or percentage, of the quantity of (red/[red + green]) fluorescence reported on an expanded scale from 0 to 1000 . The percentage of sperm cells falling outside the main population (COMP $\alpha \mathrm{T}$ ) reflects the percentage of cells with increased sensitivity to denaturation as compared with the cells characterizing that sample.

\section{Sperm ROS Generation}

The sperm superoxide anion $\left(\mathrm{O}_{2}^{-{ }^{-}}\right)$level was measured using a modification of a method previously described elsewhere (19). Hydroethidine (HE) is rapidly oxidized by $\mathrm{O}_{2}{ }^{-\cdot}$ to yield ethidium, which intercalates into DNA. The HE stock, which dissolves in dimethyl sulfoxide DMSO at $0.33 \mathrm{mM}$, can be directly oxidized into ethidium bromide by the $\mathrm{O}_{2}{ }^{-}$produced by sperm. The spermatozoa $\left(1 \times 10^{6}\right)$ were incubated in $1 \mathrm{~mL}$ of buffer containing HE dye $(2 \mu \mathrm{M})$ for 5 minutes. The sperm hydrogen peroxide $\left(\mathrm{H}_{2} \mathrm{O}_{2}\right)$ level, on the other hand, can be measured in most cells through the use of a fluorescent probe, $2^{\prime}, 7^{\prime}$-dichlorofluorescin diacetate (DCHFDA). The DCHF-DA probe is a stable dye that passively diffuses into cells and is hydrolyzed by intracellular esterase to yield DCHF, which is trapped inside cells. The $\mathrm{H}_{2} \mathrm{O}_{2}$ produced by cells oxidizes DCHF to the highly fluorescent compound $2^{\prime}, 7^{\prime}$-dichlorofluorescein (DCF) with a green color.

In this study, the $\mathrm{H}_{2} \mathrm{O}_{2}$ level in the sperm was evaluated by modifying the method proposed by Royall and Ischiropoulo (20). The spermatozoa $\left(1 \times 10^{6}\right)$ were incubated in $1 \mathrm{~mL}$ of buffer containing DCFH-DA dye $(12.5 \mu \mathrm{M})$ for 5 minutes. The mixture was set aside and maintained at $34^{\circ} \mathrm{C}$ for $30 \mathrm{~min}$ utes. Intracellular $\mathrm{O}_{2}{ }^{-}$and $\mathrm{H}_{2} \mathrm{O}_{2}$ levels were measured using flow cytometry. The excitation wavelength for DCF and ethidium fluorescence was $488 \mathrm{~nm}$, DCF emission was 530 $\mathrm{nm}$, and ethidium emission was $630 \mathrm{~nm}$. The percentage of red or green fluorescent spermatozoa revealed the respective percentages of sperm with excessive $\mathrm{O}_{2}{ }^{-\cdot}$ or $\mathrm{H}_{2} \mathrm{O}_{2}$ production.

\section{Statistical Analysis}

The values were expressed as mean \pm standard deviation (SD). The men's BLL were compared in relation to the vari- ables of "cigarette smoking" and "alcohol drinking" using Student's $t$-test or one-way analysis of variance (ANOVA). The comparisons between the semen quality of the low, moderate, and high BLL groups and the semen quality in relation to the number of cigarettes smoked per day were undertaken by the ANOVA method, followed by the Tukey test. Multiple linear regression models were then used to examine the relationship between BLL and semen parameters, after adjusting for smoking propensity.

To determine the relationship between sperm ROS generation and sperm chromatin DNA integrity, we applied a linear regression analysis on the sperm $\mathrm{O}_{2}{ }^{-\cdot}$ and $\mathrm{H}_{2} \mathrm{O}_{2}$ production levels and on the levels of $\alpha \mathrm{T}$ and COMP $\alpha \mathrm{T}$. Analysis of the data was undertaken using the JMP statistical package (SAS Institute, NC). All $P$ values were two-sided.

\section{RESULTS \\ Demographic Data and BLL}

The descriptive statistics on the study population in terms of propensity for cigarette smoking and alcohol drinking are provided in Table 1. The background characteristics of the participants and nonparticipants were similar. The men were routinely exposed to lead in their workplace; the average length of exposure to lead was 1.7 years, and the average BLL was $40.2 \mu \mathrm{g} / \mathrm{dL}$. Approximately $52 \%$ of the study participants reported that they were current smokers, and $83 \%$ were current drinkers. As shown in Table 2, when the workers were divided into smoking and nonsmoking groups, the BLL of the 42 smokers was $43.0 \pm 13.1 \mu \mathrm{g} / \mathrm{dL}$, a level that was statistically significantly higher than the $37.1 \pm 11.9 \mu \mathrm{g} / \mathrm{dL}$ BLL for the 38 men in the nonsmoking group $(P=.042)$.

\begin{tabular}{|c|c|c|}
\hline \multicolumn{3}{|c|}{$\begin{array}{l}\text { Characteristics of study participants and } \\
\text { nonparticipants. }\end{array}$} \\
\hline Parameters & $\begin{array}{l}\text { Participants } \\
(\mathrm{n}=80)\end{array}$ & $\begin{array}{l}\text { Nonparticipants } \\
\quad(n=87)\end{array}$ \\
\hline Age (years) & $29.2 \pm 3.9$ & $33.2 \pm 5.2$ \\
\hline Body height (cm) & $166.3 \pm 4.5$ & $168.5 \pm 6.6$ \\
\hline Body weight $(\mathrm{kg})$ & $60.7 \pm 6.5$ & $63.2 \pm 7.1$ \\
\hline $\begin{array}{l}\text { Body mass } \\
\text { index }\left(\mathrm{kg} / \mathrm{m}^{2}\right)\end{array}$ & $21.9 \pm 2.1$ & $22.3 \pm 2.8$ \\
\hline $\begin{array}{l}\text { Working duration } \\
\text { (years) }\end{array}$ & $1.7 \pm 0.7$ & $2.1 \pm 1.3$ \\
\hline $\begin{array}{l}\text { Blood lead } \\
\text { levels }(\mu \mathrm{g} / \mathrm{dL})\end{array}$ & $40.2 \pm 12.8$ & (no data) \\
\hline $\begin{array}{l}\text { Cigarette } \\
\text { smoking } \\
(\%, \mathrm{Y} / \mathrm{N})\end{array}$ & $\begin{array}{l}52.5 \% \\
(42 / 38)\end{array}$ & $\begin{array}{l}48.3 \% \\
(42 / 45)\end{array}$ \\
\hline $\begin{array}{l}\text { Alcohol drinking } \\
(\%, \mathrm{Y} / \mathrm{N})\end{array}$ & $\begin{array}{l}82.5 \% \\
(66 / 14)\end{array}$ & $\begin{array}{l}78.2 \% \\
(68 / 19)\end{array}$ \\
\hline
\end{tabular}




\section{TABLE 3}

Comparisons of semen quality from three blood lead levels (BLL) in 80 battery plant workers.

\begin{tabular}{|c|c|c|c|c|}
\hline \multirow[b]{2}{*}{ Parameters } & \multicolumn{3}{|c|}{$\begin{array}{l}\text { Blood lead } \\
\text { levels }(\mu \mathrm{g} / \mathrm{dL})\end{array}$} & \multirow[b]{2}{*}{$P$ value } \\
\hline & $<25(n=14)$ & $25-45(n=38)$ & $>45(n=28)$ & \\
\hline BLL mean (min/max) & $21.3(10.5 / 24.9)$ & $37.3(26.9 / 45.0)$ & $53.3(45.7 / 70.9)$ & \\
\hline Semen volume (mL) & $2.3 \pm 1.2$ & $2.2 \pm 1.2$ & $2.4 \pm 1.4$ & .771 \\
\hline Sperm count $\left(10^{6} / \mathrm{mL}\right)$ & $50.5 \pm 41.4$ & $78.5 \pm 63.0$ & $58.5 \pm 48.9$ & .184 \\
\hline Motility (\%) & $43.6 \pm 22.9$ & $48.7 \pm 18.8$ & $44.5 \pm 19.1$ & .598 \\
\hline Morphologic abnormality (\%) & $30.4 \pm 6.2$ & $34.4 \pm 7.7$ & $39.4 \pm 6.9^{\mathrm{a}, \mathrm{b}}$ & $<.001$ \\
\hline Head abnormality (\%) & $9.7 \pm 5.8$ & $12.3 \pm 7.2$ & $18.1 \pm 6.7^{\mathrm{a}, \mathrm{b}}$ & $<.001$ \\
\hline Neck abnormality (\%) & $3.8 \pm 2.8$ & $3.7 \pm 2.2$ & $4.1 \pm 2.4$ & .812 \\
\hline Tail abnormality (\%) & $9.4 \pm 6.3$ & $12.6 \pm 9.2$ & $11.9 \pm 8.3$ & .480 \\
\hline Immaturity (\%) & $7.5 \pm 1.6$ & $5.8 \pm 3.9$ & $5.3 \pm 3.5$ & .143 \\
\hline \multicolumn{5}{|c|}{ Computer-assisted semen analysis (CASA) } \\
\hline VCL $(\mu \mathrm{m} / \mathrm{s})$ & $97.7 \pm 29.9$ & $90.5 \pm 26.7$ & $100.1 \pm 29.2$ & .384 \\
\hline $\operatorname{VAP}(\mu \mathrm{m} / \mathrm{s})$ & $49.7 \pm 16.6$ & $46.5 \pm 16.9$ & $54.3 \pm 20.8$ & .248 \\
\hline $\operatorname{VSL}(\mu \mathrm{m} / \mathrm{s})$ & $36.1 \pm 15.0$ & $34.0 \pm 15.0$ & $41.9 \pm 21.6$ & .209 \\
\hline $\mathrm{ALH}(\mu \mathrm{m})$ & $6.1 \pm 3.0$ & $5.4 \pm 4.0$ & $4.9 \pm 3.0$ & .604 \\
\hline $\mathrm{BCF}(\mathrm{Hz})$ & $37.1 \pm 15.3$ & $40.1 \pm 14.4$ & $38.4 \pm 12.5$ & .782 \\
\hline \multicolumn{5}{|c|}{ Sperm chromatin structure assay (SCSA) } \\
\hline$\alpha T$ & $429.4 \pm 58.4$ & $480.6 \pm 62.8^{a}$ & $488.0 \pm 60.4^{\mathrm{a}}$ & .012 \\
\hline COMP $\alpha \mathrm{T}(\%)$ & $65.2 \pm 8.9$ & $77.0 \pm 11.8^{a}$ & $75.6 \pm 9.2^{\mathrm{a}}$ & .002 \\
\hline \multicolumn{5}{|c|}{ Percentage of sperm with reactive oxygen species (ROS) production } \\
\hline $\mathrm{O}_{2}^{-\cdot}(\%)$ & $70.3 \pm 10.4$ & $75.3 \pm 15.7$ & $78.2 \pm 9.9$ & .188 \\
\hline $\mathrm{H}_{2} \mathrm{O}_{2}(\%)$ & $7.8 \pm 13.4$ & $8.6 \pm 17.3$ & $8.9 \pm 21.7$ & .983 \\
\hline \multicolumn{5}{|c|}{$\begin{array}{l}\text { Abbreviations: } \alpha \mathrm{T} \text { : the extent of DNA denaturation per cell; ALH: amplitude of lateral displacement for all sperm after ad- } \\
\text { justment; BCF: beat frequency for all sperm after adjustment; COMP } \alpha \mathrm{T} \text { : the percentage of sperm with increased sen- } \\
\text { sitivity to DNA denaturation; VAP: average path velocity for all sperm after adjustment; VCL: curvilinear velocity for all } \\
\text { sperm after adjustment; VSL: straight-line velocity for all sperm after adjustment. } \\
\text { a } P<.05 \text { as compared with low exposure group ( }<25 \mu \mathrm{g} / \mathrm{dL}) \text {. } \\
\text { b } P<.05 \text { as compared with moderate exposure group ( } 25-45 \mu \mathrm{g} / \mathrm{dL}) \text {. }\end{array}$} \\
\hline Hsu. Lead exposure and sperm chromatin DNA & e. Fertil Steril 2009. & & & \\
\hline
\end{tabular}

The present study clearly demonstrates the statistically significant differences in BLL between smokers and nonsmokers, providing strong support for the results reported in previous studies (21-23). Tobacco plants, like many other plants, will invariably contain certain amounts of lead absorbed from the soil; however, lead may also be deposited on the surface of the leaves. The widespread use of lead arsenate as a pesticide on tobacco crops has, in the past, resulted in lead contamination of tobacco products. The 80 workers at the factory fell into various job categories, including battery assembly, analysis, packaging, and lead cutting; and, in addition to occupational exposure, smoking may be another major source of lead exposure. Chuang et al. (24) reported that, as health promotion programs generally reduced worker exposure to lead, the greatest reduction in lead exposure was achieved as a result of banning smoking within the workplace.

Many other studies have also demonstrated that the poor personal hygiene habits among workers, such as smoking and food consumption in the workplace, as well as body and clothing-mediated contamination, may represent a substantial contribution to the overall uptake of lead through inadvertent contact and ingestion (25-27). Of all of the methods of uptake, lead contamination of the mouth and hands has been recognized as the most immediate source for exposed workers (25). In this study, we have found a positive association between the BLL of workers and the number of cigarettes smoked per day, which suggests a strong association between lead absorption and smoking, either from smoking lead-contaminated cigarettes or as a result of touching the lips with contaminated hands. Hence, from a practical standpoint, lead-handling workers should be advised to improve their hygiene by refraining from smoking in the workplace, regularly washing their hands and face, and bathing immediately after their day's work.

Several epidemiologic studies have demonstrated that lead may induce DNA strand breaks in the lymphocytes of 


\section{FIGURE 1}

Relationship between percentage of sperm with excessive superoxide anion production and $(\mathbf{A})$ chromatin DNA denaturation per cell and $(B)$ percentage of sperm with DNA denaturation $(r=0.47$ and $0.35 ; P<.0001$ and $P=.0013$, respectively). Observations from three groups of blood lead levels (BLL) are shown by open circles, solid triangles, and solid circles, respectively.
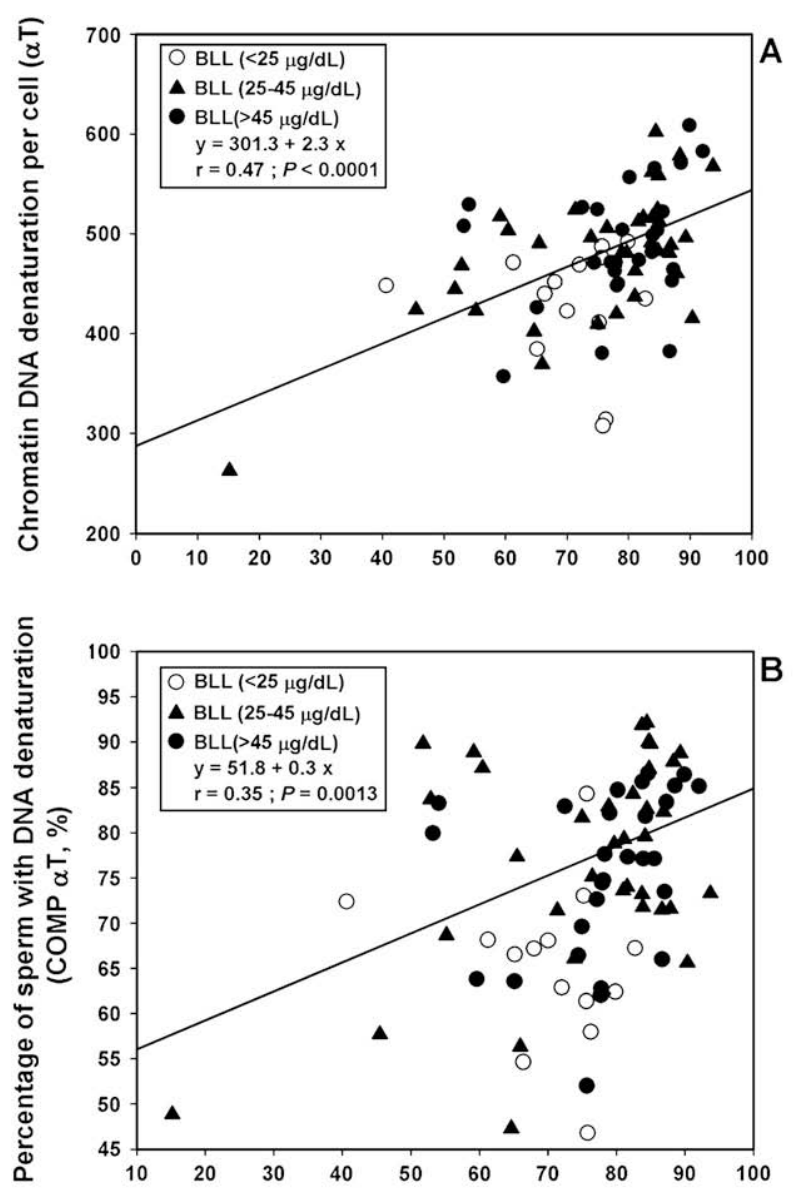

Percentage of sperm with superoxide anion $\left(\mathrm{O}_{2}{ }^{-}\right)$production $(\%)$

Hsu. Lead exposure and sperm chromatin DNA damage. Fertil Steril 2009.

The findings of our study suggest that workers who are routinely exposed to lead within the workplace are at a higher risk of damage to sperm morphology and chromatin DNA integrity. Our results also suggest that cigarette smoking has a clear association with elevated BLL. We therefore propose that BLL can be used as a biomarker for predicting sperm abnormalities because, after adjusting for smoking propensity, we find that BLL is directly related to morphologic abnormality as well as $\alpha \mathrm{T}$ and COMP $\alpha \mathrm{T}$ levels.

Acknowledgments: The authors thank Mr. Wen-Chia Cheng and Ms. Li-Ho Tseng for their technical assistance during the workers contacts and SCSA measurements.

\section{REFERENCES}

1. Feychting M, Plato N, Nise G, Ahlbom A. Paternal occupational exposures and childhood cancer. Environ Health Perspect 2001;109:193-6.

2. Winder C, Bonin T. The genotoxicity of lead. Mutat Res 1993;285: $117-24$.

3. Wozniak K, Blasiak J. In vitro genotoxicity of lead acetate: induction of single and double DNA strand breaks and DNA-protein cross-links. Mutat Res 2003;535:127-39.

4. Balhorn R. A model for the structure of chromatin in mammalian sperm. J Cell Biol 1982;93:298-305.

5. Xu D-X, Shen H-M, Zhu Q-X, Chua L, Wang Q-N, Chia S-E, et al. The associations among spermatozoa and concentrations of cadmium, lead and selenium in seminal plasma. Mutat Res 2003;534:155-63.

6. Fracasso ME, Perbellini L, Solda S, Talamini G, Franceschetti P. Lead induced DNA strand breaks in lymphocytes of exposed workers: role of reactive oxygen species and protein kinase C. Mutat Res 2002;515: 159-69.

7. Danadevi K, Rozati R, Banu BS, Rao PH, Grover P. DNA damage in workers exposed to lead using comet assay. Toxicology 2003;187: 183-93.

8. Chen Z, Lou J, Chen S, Zheng W, Wu W, Jin L, et al. Evaluating the genotoxic effects of workers exposed to lead using micronucleus assay, comet assay and TCR gene mutation test. Toxicology 2006;223:219-26.

9. Saleh RA, Agarwal A, Nelson DR, Nada EA, El-Tonsy MH, Alvarez JG, et al. Increased sperm nuclear DNA damage in normozoospermic infertile men: a prospective study. Fertil Steril 2002;78:313-8.

10. Sharma RK, Said T, Agarwal A. Sperm DNA damage and its clinical relevance in assessing reproductive outcome. Asian J Androl 2004;6: $139-48$.

11. Muriel L, Garrido N, Fernandez JL, Remohi J, Pellicer A, de los Santos MJ, et al. Value of the sperm deoxyribonucleic acid fragmentation level, as measured by the sperm chromatin dispersion test, in the outcome of in vitro fertilization and intracytoplasmic sperm injection. Fertil Steril 2006;85:371-83.

12. Evenson DP, Jost L. Sperm chromatin structure assay for fertility assessment. Methods Cell Sci 2000;22:169-89.

13. Sanchez-Pena LC, Reyes BE, Lopez-Carrillo L, Recio R, MoranMartinez J, Cebrian ME, et al. Organophosphorous pesticide exposure alters sperm chromatin structure in Mexican agricultural workers. Toxicol Appl Pharmacol 2004;196:108-13.

14. Poli G, Leonarduzzi G, Biasi F, Chiarpotto E. Oxidative stress and cell signalling. Curr Med Chem 2004;11:1163-82.

15. Institute of Occupational Safety and Health (IOSH). Recommended method for blood lead measurement. Taipei, Taiwan: Executive Yuan, 2002.

16. CLA. Council of Labor Affairs. QC/QA program for blood lead measurement. Taipei, Taiwan: Executive Yuan, 2006.

17. World Health Organization. Laboratory manual for the examination of human semen and semen-cervical mucus interaction. 4th ed. Cambridge: Cambridge University Press, 1999.

18. Evenson DP, Jost LK, Baer RK, Turner TW, Schrader SM. Individuality of DNA denaturation patterns in human sperm as measured by the sperm chromatin structure assay. Reprod Toxicol 1991;5:115-25.

19. Marchetti C, Obert G, Deffosez A, Formstecher P, Marchetti P. Study of mitochondrial membrane potential, reactive oxygen species, DNA fragmentation and cell viability by flow cytometry in human sperm. Hum Reprod 2002;17:1257-65.

20. Royall JA, Ischiropoulos $\mathrm{H}$. Evaluation of $2^{\prime}, 7^{\prime}$-dichlorofluorescin and dihydrorhodamine-123 as fluorescent probes for intracellular $\mathrm{H}_{2} \mathrm{O}_{2}$ in cultured endothelial cells. Arch Biochem Biophys 1993;302:348-55.

21. Wolfsperger M, Hauser G, Gossler W, Schlagenaufen C. Heavy metals in human hair samples from Austria and Italy: influence of sex and smoking habits. Sci Total Environ 1994;156:235-42.

22. Kristiansen J, Christensen JM, Iversen BS, Sabbioni E. Toxic trace element reference levels in blood and urine: influence of gender and lifestyle factors. Sci Total Environ 1997;204:147-60.

23. Mortada WI, Sobh MA, El-Defrawy MM, Farahat SE. Reference intervals of cadmium, lead, and mercury in blood, urine, hair, and nails among 
residents in Mansoura city, Nile Delta, Egypt. Environ Res 2002;90: 104-10.

24. Chuang HY, Lee MLT, Chao KY, Hu H. Relationship of blood lead levels to personal hygiene habits in lead battery workers: Taiwan, 1991-1997. Am J Ind Med 1999;35:595-603.

25. Far HS, Pin NT, Kong CY, Fong KS, Kian CW, Yan CK. An evaluation of the significance of mouth and hand contamination for lead absorption in lead-acid battery workers. Int Arch Occup Environ Health 1993;64: 439-43.

26. Askin DP, Volkmann M. Effect of personal hygiene on blood lead levels of workers at a lead processing facility. Am Ind Hyg Assoc J 1997;58: 752-3.

27. Lai JS, Wu TN, Liou SH, Shen CY, Guu CF, Ko KN, et al. A study of the relationship between ambient lead and blood lead among lead battery workers. Int Arch Occup Environ Health 1997;69:295-300.

28. Foster WG, McMahon A, Rice DC. Sperm chromatin structure is altered in cynomolgus monkeys with environmentally relevant blood lead levels. Toxicol Ind Health 1996;12:723-35.

29. Hernandez-Ochoa M, Sanchez-Gutierrez M, Solis-Heredia MJ, Quintanilla-Vega B. Spermatozoa nucleus takes up during the epididymal maturation altering chromatin condensation. Reprod Toxicol 2006;21: $171-8$.

30. Aravindan GR, Bjordahl J, Jost LK, Evenson DP. Susceptibility of human sperm to in situ DNA denatured is strongly correlated with DNA strand breaks identified by single-cell electrophoresis. Exp Cell Res 1997;236:231-7.

31. Lopes S, Sun J-G, Jurisicova A, Meriano J, Casper RF. Sperm deoxyribonucleic acid fragmentation is increased in poor-quality semen samples and correlates with failed fertilization in intracytoplasmic sperm injection. Fertil Steril 1998;69:528-32.
32. Morel F, Mercier S, Roux C, Elmrini T, Clavequin MC, Bresson HK. Interindividual variations in the disomy frequencies of human spermatozoa and their correlation with nuclear maturity as evaluated by aniline blue staining. Fertil Steril 1998;69:1122-7.

33. Aitken R, Ryan A, Curry B, Baker M. Multiple forms of redox activity in populations of human spermatozoa. Mol Hum Reprod 2003;9:645-61.

34. Twigg J, Fulton N, Gomez E, Irvine D, Aitken R. Analysis of the impact of intracellular reactive oxygen species generation on the structural and functional integrity of human spermatozoa: lipid peroxidation, DNA fragmentation and effectiveness of antioxidants. Hum Reprod 1998;13: 1429-36.

35. Vernet P, Fulton N, Wallace C, Aitken R. Analysis of reactive oxygen species generating systems in rat epididymal spermatozoa. Biol Reprod 2001;65:1102-13.

36. Said TM, Agarwal A, Sharma RK, Thomas AJ, Sikka SC. Impact of sperm morphology on DNA damage caused by oxidative stress induced by $\beta$-nicotinamide adenine dinucleotide phosphate. Fertil Steril 2005;83: 95-103.

37. Hsu PC, Liu MY, Hsu CC, Chen LY, Guo YL. Lead exposure causes generation of reactive oxygen species and functional impairment in rat sperm. Toxicology 1997;122:133-43.

38. Hsu PC, Hsu CC, Liu MY, Chen LY, Guo YL. Lead-induced changes in spermatozoa function and metabolism. J Toxicol Environ Health 1998;55:45-64.

39. Acharya UR, Rathore RM, Mishra M. Role of vitamin C on lead acetate induced spermatogenesis in swiss mice. Enviro Toxicol Pharmacol 2003;13:9-14.

40. Guzick DS, Overstreet JW, Factor-Litvak P, Brazil CK, Nakajima ST, Coutifaris C, et al. Sperm morphology, motility, and concentration in fertile and infertile men. N Engl J Med 2001;345:1388-93. 